\title{
Delayed biodiversity change: no time to waste
}

\section{Franz Essl ${ }^{1,2,3}$, Stefan Dullinger ${ }^{3}$, Wolfgang Rabitsch ${ }^{2}$, Philip E. Hulme ${ }^{4}$, Petr Pyšek ${ }^{5,6}$, John R.U. Wilson ${ }^{1,7}$, and David M. Richardson ${ }^{1}$}

\author{
${ }^{1}$ Centre for Invasion Biology, Department of Botany and Zoology, Stellenbosch University, Private Bag X1, Matieland 7602, \\ South Africa \\ ${ }^{2}$ Environment Agency Austria, Spittelauer Lände 5, 1090 Vienna, Austria \\ ${ }^{3}$ Division of Conservation Biology, Vegetation and Landscape Ecology, Faculty Centre of Biodiversity, University of Vienna, \\ Rennweg 14, 1030 Vienna, Austria \\ ${ }^{4}$ The Bio-Protection Research Centre, Lincoln University, PO Box 84850, Canterbury, New Zealand \\ ${ }^{5}$ Institute of Botany, Department of Invasion Ecology, The Czech Academy of Sciences, 25243 Průhonice, Czech Republic \\ ${ }^{6}$ Department of Ecology, Faculty of Science, Charles University in Prague, Viničná 7, 12844 Praha 2, Czech Republic \\ ${ }^{7}$ South African National Biodiversity Institute, Kirstenbosch Research Centre, Claremont, 7735, South Africa
}

\begin{abstract}
Delayed biodiversity responses to environmental forcing mean that rates of contemporary biodiversity changes are underestimated, yet these delays are rarely addressed in conservation policies. Here, we identify mechanisms that lead to such time lags, discuss shifting human perceptions, and propose how these phenomena should be addressed in biodiversity management and science.
\end{abstract}

\section{Environmental change and delayed biodiversity responses}

Biodiversity often does not respond immediately to changes in the physical or biotic environment. Considerable time lags (i.e., relaxation times) are involved in these responses [1,2]. However, the mechanisms at work, and the factors (e.g., feedbacks or abrupt changes at thresholds) that mediate delayed biodiversity responses to environmental forcing are manifold and poorly understood. Consequently, the full spectrum of consequences of rapid environmental changes on biodiversity is difficult to contextualize and, thus, the implications are easily underestimated. Here, we expand on recent assessments of these phenomena [2] by formulating 12 mechanisms that contribute to delayed biodiversity responses (Table 1), discuss how human perceptions regarding environmental change typically result in slow societal response, and then provide priorities for science and management on how to address this problem to mitigate future attrition of biodiversity.

\section{Progress and limitations in understanding the mechanisms of delayed biodiversity responses}

Delayed biodiversity responses to environmental forcing have been well studied over the past two decades, especially in the context of habitat loss and fragmentation. Mechanisms and implications have been intensively explored after the phenomenon of extinction debt was proposed by Tilman et al. [1], likely because habitat destruction is a dominant and clearly visible feature of

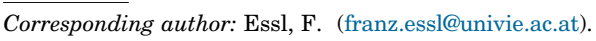

Keywords: extinction debt; global change; management; relaxation time;

shifting baselines; time lags.

0169-5347/

(C) 2015 Elsevier Ltd. All rights reserved. http://dx.doi.org/10.1016/j.tree.2015.05.002 environmental change and because it is relatively straightforward to quantify (e.g., by using time-series of changes in habitat extent that can be backcast using historical maps). However, recent work has highlighted that biodiversity shows substantially lagged responses to other changes in biotic and abiotic pressures (e.g., [3,4]), and more needs to be done to elucidate the consequences of these processes (Table 1). Moreover, studies on delayed biodiversity responses have usually focused on particular kinds of environmental change in isolation (e.g., habitat loss or range filling of invasive species) and on one or a few taxonomic groups. In reality, such changes often act simultaneously upon multiple components of biodiversity. For instance, habitat loss causes qualitative changes in the remaining habitat (e.g., due to edge effects), and alters connectivity between remaining habitat patches [4], simultaneously affecting genes, species, and communities. In the worst case, such changes result in losses of ecosystem services that contribute to human well-being, but often with delays of several decades [2,5].

Delayed biodiversity responses can, of course, lead to increases as well as declines in population sizes and species diversity in communities. Available evidence suggests that relaxation times arising from the same pressure differ in length for biodiversity losses and gains. For instance, projections of the ranges of plant species in mountains under climate change have suggested that range losses at the trailing edge will take longer to unfold than range gains at the leading edge [5], thus creating a transient species surplus.

\section{Shifting baselines undermine the assessment of long- term environmental changes}

Humans tend to undervalue environmental changes that unfold slowly and incrementally over timescales of decades relative to those that play out over a single human generation or less. In fact, assessments of environmental changes are often based on shifting baselines. As humans, we adjust our perception of the state of the environment unconsciously, based on recent impressions, giving scant attention to earlier changes [6]: the abnormal becomes the new normal. For instance, climate change during the 21st century will likely be drastic, and the global surface air temperature will probably exceed the limit of dangerous 
Table 1. Twelve mechanisms that contribute to delayed biodiversity responses ${ }^{a}$

\begin{tabular}{|c|c|c|c|c|c|}
\hline No & Mechanisms & Examples & $\begin{array}{l}\text { Relevant species } \\
\text { attributes }\end{array}$ & Consequences & $\begin{array}{l}\text { Implications for } \\
\text { management }\end{array}$ \\
\hline 2 & $\begin{array}{l}\text { Ecosystem } \\
\text { degradation (i.e., } \\
\text { qualitative } \\
\text { ecosystem } \\
\text { change) }\end{array}$ & $\begin{array}{l}\text { Input of nutrients; toxic } \\
\text { substances; loss of ecosystem } \\
\text { structures }\end{array}$ & $\begin{array}{l}\text { Life-history traits } \\
\text { that are relevant for } \\
\text { the factor implicated } \\
\text { in ecosystem } \\
\text { degradation (e.g., } \\
\text { sensitivity to toxic } \\
\text { substances) }\end{array}$ & $\begin{array}{l}\text { Delayed local population } \\
\text { and/or species diversity } \\
\text { decline and loss }\end{array}$ & $\begin{array}{l}\text { Ecosystem management; } \\
\text { long-term biodiversity } \\
\text { monitoring }\end{array}$ \\
\hline 3 & $\begin{array}{l}\text { Changes to } \\
\text { ecosystem } \\
\text { connectivity }\end{array}$ & $\begin{array}{l}\text { Increased fragmentation of } \\
\text { ecosystem patches; increased } \\
\text { connectivity (e.g., rivers } \\
\text { connected by artificial } \\
\text { waterways) }\end{array}$ & $\begin{array}{l}\text { Dispersal capacity; } \\
\text { (meta)population } \\
\text { dynamics }\end{array}$ & $\begin{array}{l}\text { Delayed increase in } \\
\text { (meta)population extinction } \\
\text { risk; delayed local population } \\
\text { and/or species diversity } \\
\text { decline and loss }\end{array}$ & $\begin{array}{l}\text { Corridor planning; 'Green } \\
\text { infrastructure' }\end{array}$ \\
\hline 5 & $\begin{array}{l}\text { Changes in } \\
\text { disturbance } \\
\text { regime }\end{array}$ & $\begin{array}{l}\text { Change in natural (e.g., fire, } \\
\text { floods) and anthropogenic (e.g., } \\
\text { traditional land-use) } \\
\text { disturbance frequencies and } \\
\text { intensities }\end{array}$ & $\begin{array}{l}\text { Species ecology } \\
\text { (e.g., serotinous } \\
\text { species for changes } \\
\text { in fire regime) }\end{array}$ & $\begin{array}{l}\text { Delayed changes in species } \\
\text { composition and ecosystem } \\
\text { structures }\end{array}$ & $\begin{array}{l}\text { Evaluate and integrate } \\
\text { lagged biodiversity } \\
\text { responses in the } \\
\text { management of natural } \\
\text { and anthropogenic } \\
\text { disturbances }\end{array}$ \\
\hline 6 & $\begin{array}{l}\text { Changes in biotic } \\
\text { interactions }\end{array}$ & $\begin{array}{l}\text { Loss or establishment of biotic } \\
\text { interactions (e.g., parasitic, } \\
\text { symbiotic, or trophic) }\end{array}$ & $\begin{array}{l}\text { Trophic position, } \\
\text { species ecology }\end{array}$ & $\begin{array}{l}\text { Delayed loss or } \\
\text { establishment of biotic } \\
\text { interactions; delayed reaction } \\
\text { of indirectly affected species } \\
\text { and/or trophic groups (e.g., } \\
\text { pollinators as a consequence } \\
\text { of a decline of plant species } \\
\text { richness due to ecosystem } \\
\text { loss) }\end{array}$ & $\begin{array}{l}\text { Consider the indirect } \\
\text { effects of lagged } \\
\text { environmental change on } \\
\text { biotic interactions in } \\
\text { biodiversity management }\end{array}$ \\
\hline 8 & $\begin{array}{l}\text { Changes in } \\
\text { biophysical } \\
\text { processes }\end{array}$ & $\begin{array}{l}\text { Changes in cycles and stocks of } \\
\text { matter and energy (e.g., } \\
\text { biomass or nutrient cycling) }\end{array}$ & Species ecology & $\begin{array}{l}\text { Delayed changes in cycles } \\
\text { and stocks of matter and } \\
\text { energy }\end{array}$ & $\begin{array}{l}\text { Sustainable use of natural } \\
\text { resources needs to take } \\
\text { into account delayed } \\
\text { responses of biophysical } \\
\text { processes }\end{array}$ \\
\hline 9 & $\begin{array}{l}\text { Selective removal } \\
\text { of species } \\
\text { (overharvesting) }\end{array}$ & $\begin{array}{l}\text { Fishing, hunting, poaching, and } \\
\text { collecting wild plants }\end{array}$ & $\begin{array}{l}\text { Interaction of the } \\
\text { species with the } \\
\text { removed species } \\
\text { (e.g., prey or } \\
\text { competition) }\end{array}$ & $\begin{array}{l}\text { Delayed decline or loss of } \\
\text { overharvested species; } \\
\text { delayed indirect effects (e.g., } \\
\text { mesopredator release); } \\
\text { delayed genetic changes of } \\
\text { the removed species (e.g., } \\
\text { due to new size-specific } \\
\text { selection pressure) }\end{array}$ & $\begin{array}{l}\text { Accounting for population } \\
\text { biology and demography } \\
\text { and indirect effects when } \\
\text { setting harvesting caps }\end{array}$ \\
\hline 10 & $\begin{array}{l}\text { Species transport } \\
\text { or invasions }\end{array}$ & $\begin{array}{l}\text { Anthropogenic translocation; } \\
\text { introduction and spread of } \\
\text { species }\end{array}$ & $\begin{array}{l}\text { Association with } \\
\text { human transport } \\
\text { pathways; dispersal } \\
\text { capacity; population } \\
\text { dynamics }\end{array}$ & $\begin{array}{l}\text { Delayed establishment, } \\
\text { range filling and population } \\
\text { density equilibrium }\end{array}$ & $\begin{array}{l}\text { Preventive measures (e.g., } \\
\text { regulations, border } \\
\text { inspections, or } \\
\text { phytosanitary measures); } \\
\text { eradication and } \\
\text { containment measures }\end{array}$ \\
\hline 11 & $\begin{array}{l}\text { Evolutionary } \\
\text { changes }\end{array}$ & $\begin{array}{l}\text { Evolutionary responses to } \\
\text { environmental changes }\end{array}$ & $\begin{array}{l}\text { Genetic diversity; } \\
\text { adaptive capacity }\end{array}$ & $\begin{array}{l}\text { Delayed evolutionary } \\
\text { adaptation to changing } \\
\text { forces }\end{array}$ & $\begin{array}{l}\text { Monitor genetic diversity } \\
\text { and consider programs to } \\
\text { maintain diversity }\end{array}$ \\
\hline 12 & Adaptive changes & $\begin{array}{l}\text { Adaptive responses (e.g., } \\
\text { behavior or phenology) of } \\
\text { species to environmental } \\
\text { changes }\end{array}$ & Phenotypic plasticity & $\begin{array}{l}\text { Delayed adaptive changes to } \\
\text { changing forces }\end{array}$ & $\begin{array}{l}\text { Difficult to integrate into } \\
\text { management decisions }\end{array}$ \\
\hline
\end{tabular}

${ }^{a}$ For further reading and references on these mechanisms, see for example, $[2,4,12]$. 
climate change of $2^{\circ} \mathrm{C}$ relative to $1850-1900$ [7]. However, a temperature increase of $2^{\circ} \mathrm{C}$ corresponds to an average annual increase of only $0.02^{\circ} \mathrm{C}$, and this warming trend is masked by substantial interannual to interdecadal climatic variability, thus making it barely discernible to humans. Such unconscious behavior undermines the full appreciation of long-term biodiversity changes and, thus, responses follow with concomitant time lags.

Implications for biodiversity research and management Time lags caused by a range of mechanisms, which are often interacting, often are in the range of decades to centuries for ecosystems and ecosystem services [2,5]. Here, we identify 12 important mechanisms for delayed biodiversity responses, provide examples, and describe both their consequences and implications for management (Table 1). Given that these prolonged delays call for adjusting priorities for biodiversity research and management, we highlight five priority areas where action is most needed (Box 1).

Most importantly, the understanding of the scale of time lags must be improved and considered in biodiversity management (Priority 1). This can be achieved by expanding existing long-term ecological monitoring networks, such as GLORIA (http://www.gloria.ac.at) and ILTER (http://www.ilternet.edu), which concomitantly record changes in pressures and monitor pathways of biodiversity responses over long timescales, using shared protocols at a global scale. However, further initiatives designed to identify causal relations between pressures and responses are urgently needed for particularly vulnerable (eco)systems (e.g., coral reefs, wetlands, or Arctic environments). Another promising avenue for assessing and projecting long-term biodiversity lags is the integration of historical data on biodiversity pressures with contemporary data on biodiversity states and trends.

Recent reviews of trends in the global status of biodiversity indicate that, while some indicators of societal responses (e.g., extent of protected areas) have improved, most biodiversity indicators continue to decline [8]. To

\section{Box 1. Five priorities to inform policy to address delayed} biodiversity responses

(1) Improve knowledge of the temporal dimension of time lags associated with different mechanisms involved in biodiversity responses and consider the outcomes of such lags in management decisions (e.g., reserve planning and management, ecosystem conservation and restoration, or spatial planning).

(2) Develop realistic long-term biodiversity projections by including inertias of biodiversity responses into biodiversity indicators and scenarios.

(3) Improve the understanding of interactions between mechanisms and of cascading effects of changing pressures through interaction networks within communities or ecosystems on resulting cumulative time lags of biodiversity responses.

(4) Improve the understanding of thresholds and tipping points, which can increase the magnitude of delayed biodiversity responses, and identify early warning-signals of approaching thresholds.

(5) Improve the understanding and make explicit the role of shifting baselines in assessing environmental changes. ensure that biodiversity indicators truly capture biodiversity trends, already known inertias in biodiversity responses (a factor not yet explicitly accounted for in these assessments) must be included to provide realistic biodiversity scenarios (Priority 2). Furthermore, interactions between mechanisms, as well as cascading effects, that cause cumulative time lags need to be taken into account (Priority 3).

For precautionary biodiversity management, the identification of robust early-warning signals (e.g., critical slowing down of recovery rates after perturbations) of approaching thresholds (tipping points) of losses of biodiversity or ecosystem services [9] is urgently needed (Priority 4). If biodiversity responses follow with substantial delay, such signals provide windows of opportunity for responses such as changes in reserve planning, land-use management, or fishery policies $[9,10]$.

Finally, it is equally vital to counteract the detrimental implications of changing human perceptions (Priority 5). These can be achieved by defining benchmarks using remaining near-pristine reference systems or by reconstructing historic conditions against which to assess changes, and by using such reference states for setting catch quota or conservation targets (e.g., [11]), as done in the European Union Water Framework Directive (http://ec. europa.eu/environment/water/water-framework/index_en. html) for example. Equally needed are studies that disentangle the psychological mechanisms involved in shifting baselines of environmental assessment [6].

\section{Concluding remarks}

The failure to give adequate consideration to the full range of mechanisms causing widespread time lags and shifting human perceptions masks the full extent of biodiversity changes that have already been triggered [2]. This situation calls for a strict application of the precautionary approach in biodiversity conservation and utilization (e.g., fishing quotas or Biodiversity targets for 2020, $c f$. https://www.cbd.int/sp/targets/) to ensure a safe operating space given that lagged biodiversity responses will never be fully accounted for. Furthermore, understanding and managing the inertia of biodiversity response requires a long-term biodiversity stewardship perspective [10].

The piecemeal understanding of delayed biodiversity changes driven by the multitude of increasing anthropogenic pressures has become a major barrier to an adequate response to the global biodiversity crisis. It is crucial that biodiversity initiatives such as IPBES (http://www.IPBES. net) and CBD (http://www.cbd.int) use their mandate to bring the likely consequences of delayed biodiversity responses to the forefront of the policy arena.

\section{Acknowledgments}

We highly appreciate the advice of one anonymous reviewer. F.E. acknowledges funding by the Austrian Climate and Energy Fund carried out within the framework of the 'ACRP' Program (Project Number KR11AC0K00355, SpecAdapt). P.P. was supported by project no. 1436079G, Centre of Excellence PLADIAS (Czech Science Foundation), long-term research development project RVO 67985939 and Praemium Academiae award from The Czech Academy of Sciences (The Czech Academy of Sciences). D.M.R. acknowledges support from the National 
Research Foundation (grant 85417). S.D. was supported by the Austrian Climate Research Programme funded research project DISEQALP (ARCPB368575)

\section{References}

1 Tilman, D. et al. (1994) Habitat destruction and the extinction debt. Nature 371, 65-66

2 Essl, F. et al. (2015) Historical legacies accumulate to shape future biodiversity in an era of rapid global change. Divers. Distrib. 21, $534-547$

3 Dullinger, S. et al. (2012) Extinction debt of high-mountain plants under 21st century climate warming. Nature Clim. Change 2, 619-622

4 Hylander, K. and Ehrlén, J. (2013) The mechanisms causing extinction debts. Trends Ecol. Evol. 28, 341-346
5 Svenning, J.C. and Sandel, B. (2013) Disequilibrium vegetation dynamics under future climate change. Am. J. Bot. 100, 1266-1286

6 Papworth, S.K. et al. (2009) Evidence for shifting baseline syndrome in conservation. Conserv. Lett. 2, 93-100

7 IPCC (2013) Climate Change 2013. The Physical Science Basis, IPCC

8 Tittensor, D.P. et al. (2014) A mid-term analysis of progress towards international biodiversity targets. Science 346, 241-244

9 Scheffer, M. et al. (2009) Early warning signals for critical transitions. Nature 461, 53-59

10 Rockström, J. et al. (2009) A safe operating space for humanity. Nature $461,472-475$

11 Jackson, J.B.C. et al. (2012) Shifting Baselines, Island Press

12 Jackson, T. and Sax, D.F. (2009) Balancing biodiversity in a changing environment: extinction debt, immigration credit and species turnover. Trends Ecol. Evol. 25, 153-160 